\title{
Religion and the Environment: Twenty-First Century American Evangelicalism and the Anthropocene
}

\author{
Marisa Ronan \\ Centre for Environmental Humanities, School of Histories and Humanities, Trinity College Dublin, College \\ Green, Dublin 2, Ireland; ronanm@tcd.ie
}

Received: 30 August 2017; Accepted: 30 October 2017; Published: 16 November 2017

\begin{abstract}
This paper provides an overview of the emergence of religion and the environment as an area of academic research and an assessment of the potential role religion can play in addressing anthropogenic climate change. Focusing on the United States of America the study traces the dynamics of anthropogenic climate change denial and offers an overview of the complex and far-reaching evangelical endeavours that seek to limit solutions and approaches to address global change issues. While much research has explored the positive role religion can play in addressing climate change, little research explores the lengths to which American evangelicals have sought to stymie climate change activism within their ranks and the potential political impact of their endeavours. As such the paper fits neatly with the theme of "Humanities for the Environment" special edition and has the capacity to contribute new insights on the impact of religion and the environment.
\end{abstract}

Keywords: religion and the environment; global change; anthropocene; evangelicalism; climate change denial

\section{Introduction}

Since the 1960s, there has been growing scholarly interest in the relationships between human cultures, religions and environments, not only among religious studies scholars, but also among philosophers who have been pioneering the field of Environmental Ethics (Benson 2000; Taylor 2005; Deane-Drummond and Strohm 2011). As a field of study, religion and ecology has generated a large body of scholarship since the 1990s (Birch et al. 1990; Gottlieb 2006; Kinsley 1995; Boyd 1999; Schultz et al. 2000; Anderson 2012; Veldman et al. 2012). The Harvard University Center for the Study of World Religions "Religion and Ecology" series, launched in 1996, helped to establish an interdisciplinary dialogue on the environmental crisis. The series included 10 conferences at Harvard and the U.N., culminating in 10 edited volumes examining the ecological implications of the beliefs, attitudes, rituals, and doctrines of various world religions in order to discover what they might offer to pragmatic aspects of public policy and environmental ethics. The volumes are generally considered to be the genesis of the religion/ecology field and today, more than 260 scholars in the U.S. and a network of 8000 people around the world explore these converging perspectives (Palmer 2012).

The Yale Forum for Religion observes that the study of religion and ecology has grown to become an academic field that engages in dialogue with other disciplines (e.g., science, economics, education, public policy) in seeking comprehensive solutions to both global and local environmental problems. Along with the Encyclopedia of Religion and Nature (2005), several journals now focus on the area including Worldviews: Religion, Culture, Environment, and Journal for the Study of Religion, Nature \& Culture, the International Society for the Study of Religion, Nature and Culture (ISSRNC) and The Journal for the Study of Religion, Nature $\mathcal{E}$ Culture. Historically, spiritual teachings have celebrated and consecrated our ties to the non-human world (Gottlieb 2004). Various systems of faith have an embedded belief that man has the capacity to manipulate the natural world through prayer and religious practice 
(Radin 1957; Lowie 1970). Scholars have conceptualised religion as a system of meaning that can provide answers to central questions about behaviours, social order, and human motivation. As such, religion can be understood as operating on multiple scales: individual and collective, local, regional and transnational (Veldman et al. 2014). Reynolds and Tanner's (1995) study on the social ecology of religion shows that throughout history religions have shaped human behavior, survival, and adaptation: "as pervasive and powerful forces in the lives of the majority of the world's people, religions are, at least in theory, well positioned to mobilize millions of people on the issue of climate change" (Veldman et al. 2014, p. 258).

Many religions have viewed the degradation of the natural environment as a moral failing and positively link ecological awareness with the notion of stewardship, a sacred obligation to safeguard and preserve the earth (Kanagy and Willits 1993; Shaiko 1987; Shibley and Wiggins 1997; Wilkinson 2012; Veldman et al. 2014). A growing collection of research explores how world religions, individually and collectively, can positively address anthropogenic climate change (Posas 2007; Reder 2012; Tucker and Grim 2001). Pope Francis's recent 192-page encyclical, “On Care for our Common Home," released in June 2015 is a clear indication of the potential for religion to highlight the human role in climate change- "a global problem with grave implications: environmental, social, economic, political, and for the distribution of goods" (Francis 2015). Importantly, the Pontiff asserted that Christians have misinterpreted Scripture and "must forcefully reject the notion that our being created in God's image and given dominion over the earth justifies absolute domination over other creatures" (Francis 2015). Historian, Lynn White Jr. in his pivotal essay, "The Historical Roots of our Ecologic Crisis" (White 1967) argued that Christianity bears significant responsibility for our modern ecological crises. He cited the belief in biblical dominionism and an associated anthropocentrism as being responsible for normalising the exploitation of the natural world. Christianity, White argued, "in absolute contrast to ancient paganism and Asia's religions (except, perhaps, Zorastrianism), not only established a dualism of man and nature but also insisted that it is God's will that man exploit nature for his proper ends" (White 1967). Nearly half a century later White's thesis is more relevant than ever.

"The Humanities for the Environment-A Manifesto for Research and Action" (Holm et al. 2015) highlights how public responses to the crisis of the Anthropocene range from denial to despair and from alarmism to an instinctual belief in our ability to cope. Views on climate change differ among Christians and Christian denominations. Within Christianity the greening of faith can be juxtaposed against an equally vociferous ethos, which seeks to delegitimize the belief in man-made climate change. Nowhere is this clearer than within American evangelicalism, which supports both energetic environmentalism on one hand and a staunch denial of manmade climate change on the other. American evangelicals do not have monolithic views about the issue and appear influenced by a variety of predictors including affect, worldviews and environmental value orientations (Smith and Leiserowitz 2013). An analysis of evangelical reactions to and against global and planetary change offers an important insight to prevailing motivations for a highly politicised section of the American public.

"Dominionism", the belief that humankind has a duty to "fill and subdue the earth" and "turn the wilderness into a garden", has been brought into the public sphere by American evangelicals striving to inform environmental policy and frustrate endeavors designed to address human-made climate change (Spencer et al. 2005). Focusing on contemporary American Evangelicalism as a case study, I trace this growing climate change denial, the rise of anti-science rhetoric and the politicisation of global warming disbelief. Here, a humanities reading of American evangelicalism provides an insight into the dynamics of anthropogenic climate change scepticism and an overview of the complex and far-reaching evangelical endeavours that seek to limit solutions and approaches to address global change issues. This paper traces evangelical efforts to mobilize its base to actively counter attempts to draw on faith to address man made climate change. I detail the range of reactionary organizations that have sprung up in the last decade with the mission to challenge environmental policy and oppose prevailing climate science. I also explore how placing climate change within a narrative framework, authors Tim LaHaye and Craig Parshall both disseminate and reinforce evangelical skepticism about 
human-made global warming replicating in fiction the very real endeavors of organizations such as the Cornwall Alliance, the Heartland Institute, and the Non-Governmental Panel on Climate Change.

American evangelicals have long played a significant role in American culture and politics (Lindsay 2007; Brint and Schroedel 2009; Smith and Leiserowitz 2013; Lynerd 2014). A number of polls and surveys relating religious beliefs and climate change attitudes have been published, many of which focus on the attitudes of American evangelicals (e.g., Barna 2007, 2008; Maibach et al. 2008; Pew Research Center's Forum on Religion \& Public Life 2004, 2006, 2009; PRRI/RNS 2011; Jones et al. 2014). In America, white evangelical Protestants are more likely than any other religious group to be climate change skeptics. Only $27 \%$ of white evangelical Protestants are climate change believers, while $29 \%$ are sympathizers and nearly 4 -in-10 (39\%) are skeptics (PRRI/AAR) National Survey on Religion, Values, and Climate Change (PRRI/AAR 2014). As such, there exists a need to better understand the dynamics of American evangelical climate change denial. The United States is second only to China in Carbon Dioxide emissions; in 2013, $\mathrm{CO}_{2}$ accounted for about $82 \%$ of all U.S. greenhouse gas emissions from human activities (EPA 2015). Nonetheless it is clear that religious institutions do not shape popular religious sentiment in a linear way and American evangelicalism constitutes a variety of approaches to aspects relating to climate change. However, while Sherkat and Ellison (2007) have highlighted the variation in American religious attitudes to climate change they also confirm that membership in conservative denominations and church participation drives political conservatism and "[p]olitical conservatism influences environmental orientations mostly through calling into question the seriousness of environmental problem" (Sherkat and Ellison 2007, p. 82). Barker (Barker and Bearce 2013) indicates that in terms of environmentalism and religious conservatism citizens possessing shorter "shadows of the future logic" often resist public policies trading short-term costs for hypothetical long-term benefits with minority interests often successfully block majority preferences.

\section{Religion, the Environment, and the Public Sphere}

The response by religious groups and organizations can be an important element in supporting or challenging the authority of the government's position on climate change. Over the last 15 years religion and ecology activism has strengthened on both sides of the debate. Many religious organizations have sprung up in America to address environmental issues including the National Religious Partnership for The Environment (NRPE) which represents a range of Judeo-Christian communities in the United States and is an example of inter-faith collaborations that have an ecological purview. ${ }^{1}$ Kearns (2007) notes that such organizations have the ability to use religion to reframe the issue from a new perspective enabling activists "to counter the frightening message of global warming with messages of hope, faith, and concrete corporate action, or contrarily, with messages legitimizing denial or dismissal and reassurances that no response is needed" (Kearns 2007, p. 117).

Within American evangelicalism, religion has sought to both challenge the existence of and address the challenge of anthropogenic climate change (Simmons 2009). In 2006 the Evangelical Climate Initiative (ECI) "Climate Change: An Evangelical Call to Action" launched with the goal of recognizing "human-induced climate change as a serious Christian issue" (ECI 2006). Launched in February 2006 the initiative grew to include a group of over 300 senior evangelical leaders in the United States "who are convinced it is time for our country to help solve the problem of global warming" (ECI 2006). The 86 original signatories included mega-church pastor, Rick Warren and Duane Litfin, president of Wheaton College and offered a promising glimpse of the capacity for evangelicalism

1 NRPE is comprised of four major organizations that together serve over 100 million Americans: the United States Conference of Catholic Bishops (USCCB), the National Council of Churches of Christ (NCCC), the Coalition on Environment and Jewish Life (COEJL), and the Evangelical Environmental Network (EEN). It also works to incorporate environmental concerns into the agendas of religion-based social agencies such as Catholic Charities USA, the United Jewish Appeal, and the Association of Evangelical Relief and Development Agencies. 
to promote environmental stewardship. The initiative grew to include a group of over 300 senior evangelical leaders in the United States "who are convinced it is time for our country to help solve the problem of global warming" (ECI 2006). The ECI recognized "both our opportunity and our responsibility to offer a biblically based moral witness that can help shape public policy in the most powerful nation on earth, and therefore contribute to the well-being of the entire world" (ECI 2006). However, the National Association of Evangelicals did not officially back the ECI's call to action, believing that it did not represent the views of all evangelicals many of whom who rejected the notion of human caused climate change: "Since NAE represents a broad spectrum of evangelicals in the United States, they reasoned, it should not take a position on the controversy" (Nazworth 2012). Lydia Bean (Bean and Teles 2015) sees this as a failure of transpartisanship. The Christian Right leaders reacted by singling out well-known evangelical climate champions and pressured signatories to withdraw their support of the ECI call to action. Notably, "this wave of opposition was organized around the Interfaith Stewardship Alliance, a new coalition of conservative faith leaders who opposed action to fight climate change and environmental regulation that interfered with free markets". The Interfaith Stewardship Alliance is one of many such evangelical organizations which have sprouted up over the last decade coordinating concerted efforts to stymy and counter environmental efforts.

The ECI's environmental concerns elicited a strong push back from evangelical climate change skeptics who organized to counter the call for action on man-made climate change. One such organization is the Cornwall Alliance for the Stewardship of Creation, a public policy group that promotes a free-market approach to care for the environment. The Alliance is an American coalition of theologians, pastors, ministry leaders, scientists, economists, policy experts, and lay people and sees itself as an evangelical voice promoting environmental stewardship and economic development built on Biblical principles. In 2006 the Alliance released a document to critique point-by-point, the ECI's four assertions on which their "Call to Action" rests. The document, "A Call to Truth, Prudence, and Protection of the Poor: An Evangelical Response to Global Warming" (Beisner et al. 2006) argued that the ECI's four main points, including that "Human emissions of carbon dioxide and other greenhouse gases into the atmosphere as we burn fuels for energy are the main cause of global warming" are "false, probably false, or exaggerated" (Beisner et al. 2006, p. 2). In particular it contested the ECI's position that reducing carbon dioxide emissions would curtail global warming. E. Calvin Beisner, founder and spokesman for the Cornwall Alliance insists that "Man was created to rule over the earth, not be its slave, and any economic system that puts nature over humanity, as do some modern environmentalist movements, is sub-biblical" (Lienesch 1993, p. 97). Notably, Beisner has testified as an expert witness on the theology, ethics, science, and economics of climate change policy before the U.S. Senate Environment and Public Works Committee and the Energy and Environment Subcommittee of the U.S. House of Representatives Committee on Energy and Commerce and briefed the White House Council on Environmental Policy. It is evident that American evangelicals have increasingly become organised in their resistance to efforts to address climate change and that they have found success in creating pathways to impact public policy.

The Cornwall Alliance declaration was signed by scientists (including 13 Climate Scientists), medical doctors, theologians, philosophers, ethicists, and pastors. Most of the academic signatories are based in private, Christian colleges including the Institute for Creation Research and 5 signatories from Bryan College, founded in the aftermath of the 1925 Scopes Trial to establish an institution of higher education that would teach from a Christian worldview. The declaration also included the signature of G. Cornelis van Kooten, expert reviewer for the Intergovernmental Panel on Climate Change's (IPCC) Fourth Assessment Report (AR4). Van Kooten sees himself as a reluctant contributing author to the IPCC report viewing the process "as too political" (Legates and van Kooten 2014). Van Kooten has since contributed several studies for the Non-governmental International Panel on Climate Change (NIPCC) an international panel of nongovernment scientists and scholars who seek to present an alternative understanding of climate change than the IPCC. The NIPCC website asserts that "[b]ecause we are not predisposed to believe climate change is caused by human greenhouse gas emissions, 
we are able to look at evidence the Intergovernmental Panel on Climate Change (IPCC) ignores. Because we do not work for any governments, we are not biased toward the assumption that greater government activity is necessary" (NIPCC 2017). Stephen Chaudoin (Chaudoin et al. 2014) contends that American evangelicals are opposed to international climate in particular due to their distrust of international cooperation and institutions, which has been a prominent feature of evangelical politics since the beginning of the Cold War (see also McCammack 2007; McCright 2011; Nagle 2008). The NIPCC emphasis on delegitimizing government intervention is frequently promoted by the range of evangelical organizations that have emerged to counter the perceived greening of faith. The NIPCC produces its own scientific research while promoting a narrative that science has become too politicized to be trusted. They assert their organization's authority by being an alternative to the mainstream, which is perceived as being untrustworthy. This is an approach that has gained serious traction and has been fully exploited in the era of Trump's "fake news", rabid distrust of policy and policy makers and the mainstream media.

There is a mutually reinforcing interconnectedness to the evangelical organizations, which seek to promote disbelief in man-made climate change. Along with the Cornwall Alliance, founder E. Calvin Beisner is also policy advisor to The Heartland Institute, which since 2008 has published the research of the Nongovernmental International Panel on Climate Change (NIPCC). The Heartland Institute is a Chicago-based national nonprofit research organization whose mission is to "discover, develop, and promote free-market solutions to social and economic problems" (Heartland Institute 2017). In 2009 The Institute released, "Climate Change Reconsidered" an 880-page rebuttal of the Fourth Assessment Report of the Intergovernmental Panel on Climate Change (IPCC). The NIPCC document was followed in 2011 with the "Climate Change Reconsidered: 2011 Interim Report", a 400-page report containing summaries and analysis of scientific research containing 1000 new research studies. In its conclusion the document states "We are not saying anthropogenic greenhouse gases (GHG) cannot produce some warming or have not in the past. Our conclusion is that the evidence shows they are not playing a substantial role" (Idso et al. 2011, p. x).

In 2013 the NIPCC released, "Climate Change Reconsidered II: Physical Science” funded by the Heartland Institute, the Center for the Study of Carbon Dioxide and Global Change, and the Science and Environmental Policy Project (SEPP). All three organizations have received funding from Exxon Mobil. The New York Times has reported that from 1998 to 2006, Exxon Mobil, "contributed more than $\$ 600,000$ to Heartland, according to annual reports of charitable contributions from the company and company foundations" (Revkin 2009). Records filed with the IRS in 2003 by the ExxonMobil Foundation (ExxonMobil 2001) shows that it provided the Center for the Study of Carbon Dioxide and Global Change with a grant for $€ 15,000$ in 2000 (Congressional Record 2003). The ExxonMobil Foundation 2000 IRS 990 form (143) shows a donation of $€ 10,000$ to the Science and Environmental Policy Project (SEPP). SEPP's founder Fred Singer has also acted as a consultant for ExxonMobil, Shell, Unocal, Sunoil, and Acro (Goodman et al. 2008). The tendency within the human condition for humans to conceive of themselves in terms of their desire to consume is here writ large with careful structures and frameworks being manufactured by American evangelical organizations to prop up industry's self-serving assertion that anthropogenic climate change does not exist.

The Heartland Institute is endorsed by Senator James Inhofe (Republican-Oklahoma) Chairman of the United States Senate Committee on Environment and Public Works and author of The Greatest Hoax: How the Global Warming Conspiracy Threatens Your Future (Inhofe 2012). In an interview on Voice of Christian Youth America's radio (Crosstalk 2012) program, Inhofe said, citing Genesis 8: $22^{2}$ that "God's still up there", the "arrogance of people to think that we, human beings, would be able to change what He is doing in the climate is to me outrageous" (Kutney 2014, p. 108). He added,

2 While the earth remaineth, seedtime and harvest, and cold and heat, and summer and winter, and day and night shall not cease. 
Scripture that I use quite frequently on this subject is Romans 1: 25, 'They give up the truth about God for a lie and they worship God's creation instead of God, who will be praised forever.' In other words, they are trying to say we should worship the creation. We were reminded back in Romans that this was going to happen and sure enough it's happening (Crosstalk 2012).

In a 20-page brochure issued under the seal of the U.S. Senate, "The Facts and Science of Climate Change" (Inhofe 2004), Inhofe compared global warming to the Cold War and the IPCC to a Soviet style trial (Inhofe 2004). In his keynote address at the Heartland Institute's annual International Conference on Climate Change (Inhofe 2015) he charted the political success achieved in countering anthropogenic climate science within the public domain.

In this speech Inhofe applauded the Republican House majority's triumph in curtailing perceived over-regulation by the EPA (Inhofe 2015). He added that he sees his position as Chair of the United States Senate Committee on Environment and Public Works as "poetic justice" for the impediment the EPA played in his previous job as a real estate developer (Inhofe 2015). Inhofe supplied his audience with a hand-out which delineated arguments and evidence to ensure they were collectively armed to generate a new consensus on climate change. He declared that "It's not just global warming, you're on the right side of the Lord with all these things" and closed his speech with an appeal to his audience, "If you join us and we do this as a team, we will be doing the Lord's work and he will richly bless you for it. Amen" (Inhofe 2015). Here, Inhofe explicitly binds his case against anthropogenic climate change in the language of evangelical faith. His careful politicization of evangelical climate change denial is ultimately the realization of his Christian worldview with a clear goal to impact public opinion as well as public policy.

In the first one hundred days of the Donald Trump presidency it appeared that the views of Inhofe, the Heartland Institute, the Cornwall Alliance and the NIPCC rather than sitting on the periphery, will likely be at the center of governmental policy. What will this mean? No doubt such organizations have already been emboldened by the Senate approval of Scott Pruitt, a deacon of the First Baptist Church, to lead the Environmental Protection Agency. Pruitt similarly has strong ties to the fossil fuel industry, a connection exposed by the New York Times in 2014. Pruitt, then Attorney General of Oklahoma, had written a letter to the Environmental Protection Agency with the accusation that Federal regulators were grossly overestimating the amount of air pollution caused by energy companies drilling new natural gas wells in his state. The New Your Times exposé proved that the three-page letter "was written by lawyers for Devon Energy, one of Oklahoma's biggest oil and gas companies, and was delivered to him by Devon's chief of lobbying" (Lipton 2014). On 9 January 2017, E. Beisner (2017) wrote an op-ed for The Christian Post entitled, "Why Christians Should Support Scott Pruitt for EPA Administrator." In it Beisner asserts that Pruitt is not a climate change denier and discounts the belief that he has ties to the fossil industry. He quotes the Alliance's (2017) “Open Letter Supporting Scott Pruitt for EPA Administrator" which includes 53 scientists (13 climate scientists), 14 economists and legal scholars, 29 theologians, philosophers, and ethicists, and 16 pastors and other religious leaders. The letter is likely a rebuttal to the Evangelical Environmental Network (EEN) "Evangelical Open Letter to President Elect Trump, Reconsider Pruitt for EPA" that was released in mid-December 2016 (Evangelical Environmental Network 2016). The letter had the support over 70 pro-life Catholic and Evangelical leaders and 450 pro-life Christians from across the country, asking the then President-elect, Donald Trump to reconsider and withdraw the nomination of Scott Pruitt to head the Environmental Protection Agency (EPA) and to name someone with a more even handed record of protecting human life from pollution. Both letters are a clear example of the ongoing divergence of evangelical opinion on anthropogenic climate change. Further, they reveal once again the interconnectedness of evangelical organizations and their collective aim to impact public policy. A decade after the Evangelical Climate Change Initiative their concerns and the pushback it generated show no sign of abating. 


\section{Science}

The dawn of the space age demonstrated that human beings transcend nature. Science and religion are challenged by the environmental crisis, both to reevaluate the natural world and to reevaluate their dialogue with each other (Rolston 2004). Hannah Arendt (Arendt [1958] 1998) suggests that as a result of modern science's "alienation from the earth" the human capacity to start new things calls all natural limits into question (Canovan 1998, p. xi). Within evangelicalism the belief in biblical inerrancy further stymies an engagement with science as all readings must first be filtered through a specific theological lens. The evangelical reaction against the notion of man-made climate change fits into a broad picture, which Kearns (2007) identifies as:

(i) the diminishment of the authority of science over religion;

(ii) the religious right's appropriation of the postmodern critique of science as socially constructed;

(iii) the perceived threat of religious environmentalism; and,

(iv) the connection between certain strands of conservative Christianity, individualism, concepts of freedom, and market ideology.

Kahan et al.'s (2011) study of the cultural cognition of scientific consensus shows that those with an individualistic worldview are more skeptical of environmental issues and tend to oppose any policy options, especially those that include government oversight, regulation, and the free market.

Brownstein (2010) and Lehmann (2010), have shown how the rise of the Tea Party and promoted skepticism toward climate change and a hostility towards climate science and climate policies. The Pew Research Center's Forum on Religion \& Public Life (2011) analysis of the connection between the Tea Party and evangelicals showed that they draw disproportionate support from the ranks of white evangelical Protestants. The study indicated that Tea Party supporters are much more likely than registered voters as a whole to say that their religion is the most important factor in determining their opinions on these social issues. McCright (2011) expects that this political divide within the general public may further inhibit the creation of effective climate policy.

There has been significant traction made in imbuing anti-science rhetoric into the public realm, none perhaps more significantly that the Louisiana Science Education Act (LSEA 2008), which further opened the door to climate science denial in the classroom. Couched under the idea of promoting "open discussion of scientific theories," the Act is an "academic freeedom law" based on the Discovery Institute's academic model statute (LSEA 2008). The Discovery Institute, a creationist think-tank, is concerned with the role that science can "advance free markets, illuminate public policy and support the theistic foundations of the West" (www.discover.org). The Institute's "Teach the Controversy" campaign seeks to teach Intelligent Design alongside Evolutionary theory and has included global warming as a topic of controversy within this strategy. The Louisiana Act was later followed by another Discovery Institute-backed bill in Tennessee. The 2013 Kansas "School Districts; Course of Instruction; Science" bill, since defeated, stated:

Certain scientific topics, such as climate science, may be controversial. The legislature encourages the teaching of such scientific controversies to be made in an objective manner in which both the strengths and weaknesses of such scientific theory or hypothesis are covered. (School districts; Course of Instruction; science (Legislation 2013)).

George Gilder, co-founder of the Discovery Institute endorsed the Cornwall Alliance's declaration, "Protect the Poor: Ten Reasons to Oppose Harmful Climate Change Policies" (Cornwall Alliance 2014). The study asserts that,

While human addition of greenhouse gases, particularly carbon dioxide $\left(\mathrm{CO}_{2}\right)$, to the atmosphere may slightly raise atmospheric temperatures, observational studies indicate that the climate system responds more in ways that suppress than in ways that amplify $\mathrm{CO}_{2}$ 's effect on temperature, implying a relatively small and benign rather than large and dangerous warming effect (Legates and van Kooten 2014, p. 1). 
The document goes on to call on Christian leaders "to study the issues and embrace sound scientific, economic, and ethical thinking on creation stewardship, particularly climate change" (Cornwall Alliance 2014). The report reflects wider evangelical skepticism about man-made climate change with $62 \%$ believing that cyclical climate change is not primarily caused by human activity (Barna 2008). In 2014, 66\% of the Senate Republican Caucus denied the existence of Climate Change (Atkin 2014).

In 2010 the Cornwall Alliance published the book, Resisting the Green Dragon: Dominion, Not Death authored by James Wanliss and endorsed by Focus on the Family. The book's chapters include, "The Church Complicit: How Environmentalism Has Penetrated the Church with Anti-Human and Anti-Christian Ideas" and "Dominion: How Humans' Filling and Subduing the Earth Can Release It from Bondage." Wanliss sees environmentalists as an active hostility towards humanity and identified the Church as "remarkably susceptible to green guilt manipulation" and asserts that nature "is not only not divine but it is not eternal" (Wanliss 2010, p. 16). Significantly, in terms of the Anthropocene, the book declares that "[r]ather than humankind being earth destroyers, it turns out that only our filling and ruling the Earth to God's glory can release it from the genesis curse. [ ... ] Therein lies hope for the entire cosmos" (Wanliss 2010, p. 17).

Perhaps one of the most interesting manifestations of the evangelical pushback to the ECI-type greening of faith has taken place within the pages of popular evangelical fiction. This is clearly evoked in evangelical minister and New York Times best-selling author of popular Christian fiction, Tim LaHaye's recent series of novels which he co-wrote with Craig Parshall. LaHaye found global success with his Left Behind series of Christian thrillers that sold over 100 million copies and achieved remarkable crossover success within a non-evangelical readership. Christian fiction as a genre has become an important tool for proselytizing outside of the pulpit, a $\$ 75$ million- $\$ 85$ million industry that has steadily grown since the 1980s. Through a short review of the End Series, I explore how a distrust in government, science and the media can be drawn upon to dismiss anthropogenic climate change and how closely the series aligns with the ethos of the Cornwall Alliance, the NIPCC and other real-world endeavors that have sought to stymie climate change action. Carr (Carr et al. 2012) shows evangelical Christians tendency toward skepticism about the existence of anthropogenic climate change. The reiteration of anthropogenic climate change disbelief in the End Series offers another avenue for evangelicals to push an agenda of doubt about environmental activism within an easy to read genre that has a built-in audience.

The "End Series" is comprised of four books, Edge of Apocalypse (2010), Thunder of Heaven (2011), Brink of Chaos (2012), and Mark of Evil (2014) and charts the imminent End of Days brought about by a United Nations-led endeavor to create a World Church Coalition, the Global Coalition of Religions. The narrative aligns with Choudoin's study which shows that many evangelicals see international institutions as stepping stones to a single world government, which some associate with the rule of the Antichrist as specified by biblical prophecy (2014). Mirroring the real work of the NIPCC the rhetoric of anti-climate change science pervades the novels. In a language that mirrors Senator James Inhofe the series' representation of "true science" specifically serves to validate god-made cataclysmic climate change that fits within a biblically foretold apocalypse. Thus the authors both dismiss the veracity of climate change while ensuring a proviso exists for any actual change in global temperatures, explaining away such temperature changes as related to volcanoes and ultimately part of God's will. The science appealed to by the novels both validates apocalyptic belief and pillories those evangelical environmentalists on the wrong side of biblical history. Within the "End Series," the novels' science of global warming is linked directly to volcanic activity.

Robert Hamilton, the novels' unsung hero, is a volcanologist from the University of Hawaii, who pinpoints the "true" cause for the rising global temperatures:

After a long and undistinguished career, Hamilton had stumbled on a discovery so stunning that it's [sic] magnitude almost defied quantification. He had his hands on a devastating assessment of an impending geological crisis. He ran through his vocabulary: apocalyptic, 
disastrous, catastrophic. All those words fit. It went far beyond his original thesis-simply that global warming trends had been spiked because of increased volcanic activity. Now the government scientists needed to know it too. ${ }^{3}$

Hamilton warns the head of the Climate Change Office of the USGS in Washington that an "environmental cataclysm is coming, and it's going to blow your global-warming ideas sky-high." Hamilton has been dismissed by the scientific establishment and is denied the opportunity to contribute to the United Nation's (UN) International Climate Conference, a clear reference to the real-world Intergovernmental Panel on Climate Change (IPCC), which has been the primary body spearheading the collection of science and the institution of international agreements to address Climate Change. Hamilton is depicted as an outsider who is ignored by the mainstream, serving to highlight to the reader the detrimental impact of what the authors see as a closed system that perpetuates "wrong" science. This belief is one that appears to be shared by the founders of the real world NIPCC who have rejected the IPCC as a UN system or cabal that suppresses alternative views and ultimately seeks to impede American sovereignty.

In Thunder of Heaven (2012) Dr. Hamilton's lecture on the cataclysmic impact of volcanoes, highlighting once again the notion that climate change is not caused by man but rather nature and thus God. Drawing on Hamilton's work the final novel reasserts this notion:

The uptick in the number and the severity of global volcanic events, which had spewed millions of tons of dust particles into the atmosphere, actually explained why suddenly global temperatures seemed to have spiked exponentially. [ ... ] If Hamilton's theory was right, the increase in temperatures was not a global-warming crisis, but a short-lived trend caused by Mother Nature that would soon even out. ${ }^{5}$

This thesis, that volcanically generated $\mathrm{CO}_{2}$ impacts climate change, is one that has also been pushed by the Cornwall Alliance and is reiterated in their document, "A Call to Truth, Prudence, and Protection of the Poor 2014: The Case against Harmful Climate Policies Gets Stronger" (Cornwall Alliance 2014).

The 'End Series' plot includes a United Nations call for collective problem solving by the global community which must be defined by strict industrial regulations: "International climate law must be preeminent and binding on every human being, on every enterprise and business, on every nation. Global cooperation of all citizens of Earth will be our urgent mission. Our survival as a species depends on it" (LaHaye and Parshall 2012, location 6986). This UN global treaty would give indomitable powers to an international climate-control coalition, which would study industrial sources of $\mathrm{CO}_{2}$ emissions and would police the activities of all private industries and nations that in any way contributed to global warming. The loss of American national sovereignty and the collapse of the economy are directly attributed to global regulations on oil. The authors see this as a "[ $t$ ]he slow, steady devolution of our nation into a socialist country that is becoming just an amalgam of one big global state. ${ }^{6 \prime}$ The 'End Series' neatly encapsulates the breadth of American evangelical climate change skepticism and presents the reader with a worst-case scenario of U.N. interference. The anti-science and anti-regulation narrative plays on the fears and suspicions of its target audience and serves to place climate-change within a biblically sanctioned End of Days. Such fears clearly align with the Cornwall Alliance and Heartland Institute as well as the Non-Governmental Panel on Climate Change. The language of the 'End Series' is one is repeated across the organizations, a reading of the Cornwall Alliance-backed book, Resisting the Green Dragon: Dominion, Not Death sees a similar emphasis on dominionism and a distrust of religious environmentalism. 
The 'End Series' shrouds its dominionism in end times prophecy, asserting that "the Bible contains God's agenda for the future of planet earth and everybody who dwells there. ${ }^{7 "}$ The Cornwall Alliance however is more explicit. "The Biblical Perspective of Environmental Stewardship: Subduing and Ruling the Earth to the Glory of God and the Benefit of Our Neighbors" (Beisner 2013) provides a list of affirmations that cite specific references to the Bible that support a dominionist perspective. Such affirmations include:

We affirm that godly dominion is a responsibility for everyone at all times.

We deny that any other terrestrial life form bears the image of God or is of equal value or priority with human beings (Matthew 10, p. 29-31).

We affirm that though the Earth is the LORD's, He has also given it to men (Psalm 115, p. 16) and mandated that they be fruitful, multiply, fill the Earth, subdue it, and have dominion over everything that lives in it (Genesis 1, p. 28).

We affirm that a comprehensive understanding of the relationship between God's placing Adam in the Garden to cultivate and guard it (Genesis 2, p. 15) and God's commanding Adam and Eve to be fruitful and multiply and fill the Earth and subdue and rule everything in it (Genesis 1, p. 28) entails a growing population that spreads out from the Garden to till the whole Earth and transform it from wilderness to garden and ultimately to garden city (Revelation 21: 2; 22: 1-3).

The list of 30 affirmations include a coopting of Biblical Stewardship to suit a dominionist perspective, "We deny that Biblical Earth stewardship, or godly dominion, is limited to keeping Earth in the condition in which man finds it." The final item denies that the expectation of divine judgment, in whatever eschatological framework, negates the need for dominionism.

Barker (Barker and Bearce 2013) indicates that in terms of environmentalism and religious conservatism citizens possessing shorter "shadows of the future logic" often resist public policies trading short-term costs for hypothetical long-term benefits with minority interests often successfully block majority preferences. As such, the question arises then, how can we address climate change denial that foresees a cataclysmic end as one not man made but rather theologically bound to a god made crises? How can we change human behavior when the end of days signifies for many a return of their savior, Jesus Christ?

Veldman (2012) exploration of how environmentally apocalyptic views are often associated with activism suggests however that not only does environmental apocalypticism exist outside of evagelicalism but that it has the capacity to motivate environmentally ethical behaviour.

\section{Conclusions}

A study of religion and the environment presents us with the complexity of reactions to climate change. Such research can identify, trace, and record the capacity for religion to revive, maintain and sustain essential planetary conditions. There has been significant development in this exchange and a large body of research has emerged since the 1990s. This paper has explored the potential for religion to stymie measures that address anthropogenic climate change. American evangelicals have proven to be savvy in their countering of faith-based environmentalism, drawing on fiction, non-fiction and the curation of scientific research publications that carefully promotes a distrust of a belief in man-made climate change. Not enough research has been completed on this topic however and as we enter the Trump era more is urgently needed. It is especially dangerous for us to assume that a greening of faith represents a defining trend in faith-based reactions to climate change. There is a clear need for

\footnotetext{
$7 \quad$ (LaHaye and Parshall 2012), location 2606.
} 
sustained research on the ability for religion to impact negatively on climate policies, it is important that a variety of religious perspectives are considered and included within global change research. The inclusion of such perspectives in this special edition reflects a positive step in this direction.

Conflicts of Interest: The author declares no conflict of interest.

\section{References}

Anderson, E. N. 2012. Anthropology of Religion and Environment: A Skeletal History to 1970. Journal for the Study of Religion, Nature and Culture 6: 9-36. [CrossRef]

Arendt, Hannah. 1998. The Human Condition, 2nd ed. Chicago: University of Chicago Press, First published 1958.

Atkin, Emily. 2014. This one Simple Graphic Explains the Difference between Climate Science and Climate Politics. Climate Progress. March 27. Available online: http:/ / thinkprogress.org/climate/2014/03/27/3419542/ climate-science-vs-climate-politics-graphic/ (accessed on 30 September 2015).

Barker, David. C., and David H. Bearce. 2013. End-Times Theology, the Shadow of the Future, and Public Resistance to Addressing Global Climate Change. Political Research Quarterly 66: 267-79. [CrossRef]

Barna. 2007. Born Again Christians Remain Skeptical, Divided About Global Warming. Research Releases in Culture \& Media, September 17. Available online: https:/ / www.barna.org/barna-update/donors-cause/ 95-born-again-christians-remain-skeptical-divided-about-global-warming\#.Vmbba7SUD3s (accessed on 19 June 2015).

Barna. 2008. Evangelicals Go "Green" with Caution. September 22. Available online: https://www. barna.org/barna-update/culture/23-evangelicals-go-qgreenq-with-caution\#.Vq81LrSUD3s (accessed on 14 November 2017).

Bean, Lydia, and Steve Teles. 2015. Spreading the Gospel of Climate Change: An Evangelical Battleground. Washington: New America, Available online: https:/ / static.newamerica.org/attachments/11649-spreading-the-gospelof-climate-change/climate_care11.9.4f0142a50aa24a2ba65020f7929f6fd7.pdf (accessed on 8 May 2017).

Beisner, E. Calvin. 2013. The Biblical Perspective of Environmental Stewardship: Subduing and Ruling the Earth to the Glory of God and the Benefit of Our Neighbors. The Cornwall Alliance. Available online: http:/ / cornwallalliance.org/landmark-documents/the-biblical-perspective-of-environmentalstewardship-subduing-and-ruling-the-earth-to-the-glory-of-god-and-the-benefit-of-our-neighbors / (accessed on 18 October 2015).

Beisner, Calvin. 2017. Why Christians Should Support Scott Pruitt for EPA Administrator. The Christian Post, January 9. Available online: http:/ / www.christianpost.com/news/why-christians-should-support-scottpruitt-for-epa-administrator-172648/\#81gamey170xeVQF8.99(accessed on 26 February 2017).

Beisner, E. Calvin, Paul K. Driessen, Ross McKitrick, and Roy W. Spencer. 2006. A Call to Truth, Prudence, and Protection of the Poor: An Evangelical Response to Global Warming. The Cornwall Alliance. Available online: http:/ / www.cornwallalliance.org/docs/a-call-to-truth-prudence-and-protection-of-thepoor.pdf (accessed on 10 October 2015).

Benson, John. 2000. Environmental Ethics: An Introduction with Readings. New York and London: Routledge.

Birch, Charles, William R. Eakin, and Jay B. McDaniel. 1990. Liberating Life: Contemporary Approaches to Ecological Theology. New York: Orbis Books.

Boyd, Heather H. 1999. Christianity and the Environment in the American Public. Journal for the Scientific Study of Religion 38: 36-44. [CrossRef]

Brint, Steven, and Jean Reith Schroedel, eds. 2009. Evangelicals and Democracy in America, Volumes I E II. New York: Russell Sage Foundation.

Brownstein, Ronald. 2010. GOP Gives Climate Science a Cold Shoulder. National Journal, October 10. Available online: http:/ / nationaljournal.com/columns/political-connections / gop-gives-climate-sciencea-cold-shoulder-20101009(accessed on 7 August 2017).

Canovan, Margaret. 1998. Introduction. In The Human Condition, 2nd ed. Chicago: University of Chicago Press.

Carr, Wylie, Michael Patterson, Laurie Yung, and Daniel Spencer. 2012. The Faithful Skeptics: Evangelical Religious Beliefs and Perceptions of Climate Change. Journal for the Study of Religion, Nature and Culture 6: 276-99. [CrossRef] 
Chaudoin, Stephen, David Thomas Smith, and Johannes Urpelainen. 2014. American Evangelicals and Domestic versus International Climate Policy. The Review of International Organizations December 9: 441-69. [CrossRef]

Congressional Record. 2003, V. 149, PT. 13, July 8-16. Available online: https:/ /www.congress.gov/congressionalrecord/2003/11/12 (accessed on 14 November 2017).

Cornwall Alliance. 2014. Protect the Poor: Ten Reasons to Oppose Harmful Climate Change Policies. Available online: http: / www.cornwallalliance.org/wp-content/uploads /2014/09/2014-Declaration-Final-Final.pdf (accessed on 22 September 2017).

Cornwall Alliance. 2017. Open Letter Supporting Scott Pruitt for EPA Administrator. Available online: http:// cornwallalliance.org/landmark-documents / open-letter-supporting-scott-pruitt-for-epa-administrator / (accessed on 26 February 2017).

Crosstalk. 2012. Voice of Christian Youth America. Inhofe: The Bible Says Global Warming Is a Hoax. Available online: https:/ / www.youtube.com/watch?v=EKd6UJPghUs (accessed on 14 November 2015).

Deane-Drummond, Celia, and Heinrich Bedford Strohm, eds. 2011. Religion and Ecology in the Public Sphere. London: Continuum.

ECI. 2006. Climate Change: An Evangelical Call to Action. The Evangelical Climate Initiative. Available online: http:/ / www.npr.org/documents/2006/feb/evangelical/calltoaction.pdf (accessed on 16 May 2015).

Environmental Protection Agency (EPA). 2015. U.S. Carbon Dioxide, Emissions and Trends. Overview of Greenhouse Gases. Available online: http:/ /www.epa.gov/climatechange/ghgemissions/gases/co2.html (accessed on 14 November 2015).

Evangelical Environmental Network. 2016. Evangelical Open Letter To President Elect Trump, Reconsider Pruitt For Epa. Available online: http:/ / www.creationcare.org/evangelical_open_letter_to_president_elect_ trump_reconsider_pruitt_for_epa (accessed on 26 February 2017).

ExxonMobil. 2001. ExxonMobil Foundation 2000 IRS 990 Form. Available online: https:/ /www.documentcloud. org/documents/1019871-2000-exxonmobil-foundation-form-990.html (accessed on 19 November 2015).

Francis, Pope. 2015. Encyclical Letter Laudato Si' of the Holy Father Francis on Care for Our Common Home. Available online: http:/ / w2.vatican.va/content/francesco/en/encyclicals/documents/papa-francesco_ 20150524_enciclica-laudato-si.html (accessed on 10 October 2015).

Goodman, Michael K., Maxwell T. Boykoff, and Evered Kyle, eds. 2008. Contentious Geographies: Environmental Knowledge, Meaning, Scale. Burlington: Ashgate.

Gottlieb, Rodger S. 2004. This Sacred Earth: Religion, Nature, Environment. New York: Routledge.

Gottlieb, Rodger S. 2006. The Oxford Handbook of Religion and Ecology. New York: Oxford University Press.

Heartland Institute. 2017. Available online: https:/ / heartland.org (accessed on 15 November 2017).

Holm, Poul, Joni Adamson, Hsinya Huang, Lars Kirdan, Sally Kitch, Iain McCalman, James Ogude, Marisa Ronan, Dominic Scott, Kirill Ole Thompson, and et al. 2015. Humanities for the Environment-A Manifesto for Research and Action. Humanities 4: 977-92. [CrossRef]

Idso, Craig D., Robert M. Carter, and S. Fred Singer, eds. 2011. Climate Change Reconsidered: 2011 Interim Report. Nongovernmental International Panel on Climate Change. Available online: http:/ /www.nipccreport.org/ reports/2011/pdf/2011NIPCCinterimreport.pdf (accessed on 17 November 2015).

Inhofe, James. 2004. The Facts and Science of Climate Change. In US Senate, Environment and Public Works; Archived from the Original PDF on 22 July 2003. Available online: http:/ / www.epw.senate.gov / repwhitepapers / ClimateChange.pdf (accessed on 15 November 2015).

Inhofe, James. 2012. The Greatest Hoax: How the Global Warming Conspiracy Threatens Your Future. Washington: WND Books.

Inhofe, James. 2015. Keynote Address, Heartland Institute's annual International Conference on Climate Change. Available online: https:/ / www.youtube.com/watch?v=BjVx3PeBIEM (accessed on 23 November 2015).

Jones, Robert P., Daniel Cox, and Juhem Navarro-Rivera. 2014. Believers, Sympathizers, \& Skeptics: Why Americans Are Conflicted about Climate Change, Environmenttal Policy, and Science. (American). Washington, D.C.: Public Religion Research Institute. Available online: http:/ / publicreligion.org/research/2014/11/believers-sympathizers-skeptics-americans-conflictedclimate-change-environmental-policy-science/\#.VmbgJbSUD3s (accessed on 6 September 2015).

Dan M. Kahan, Hank Jenkins-Smith, and Donald Braman. 2011. Cultural Cognition of Scientific Consensus. Journal of Risk Research 14: 147-74. [CrossRef] 
Kanagy, C. L., and F. K. Willits. 1993. A Greening of Religion? Some evidence from a Pennsylvania Sample. Social Science Quarterly 74: 674-83.

Kearns, Laurel. 2007. Cooking the Truth: Faith, Science, the Market and Global Warming. In Ecospirit: Religions and Philosophies for the Earth. Edited by L. Kearns and C. Keller. New York: Fordham University Press, pp. 97-124.

Kinsley, David. 1995. Ecology and Religion: Ecological Spirituality in Cross-cultural Perspective. Englewood Cliffs: Prentice Hall.

Kutney, Gerald. 2014. Carbon Politics and the Failure of the Kyoto Protocol. New York: Routledge.

LaHaye, Tim, and Craig Parshall. 2010. Edge of Apocalypse. Zondervan: Grand Rapids.

LaHaye, Tim, and Craig Parshall. 2012. Brink of Chaos. Zondervan: Grand Rapids.

Legates, David R., and G. Cornelis van Kooten. 2014. A Call to Truth, Prudence, and Protection of the Poor: The Case against Harmful Climate Policies Gets Stronger. The Cornwall Alliance. Available online: http:/ / www.cornwallalliance.org/wp-content/uploads/2014/09/A-Call-to-Truth-Prudence-and-

Protection-of-the-Poor-2014-The-Case-Against-Harmful-Climate-Policies-Gets-Stronger.pdf (accessed on 27 November 2015).

Legislation. 2013. United States of America. School Districts; Course of Instruction; Science. House Bill No. 2306, 2013 Committee on Education. Available online: http://kslegislature.org/li_2014/b2013_14/measures/ documents/hb2306_00_0000.pdf(accessed on 20 September 2015).

Lehmann, Evan. 2010. Republicans Learn the Perils of Being Politically Incorrect on Climate Change. New York Times, November 28. Available online: http:/ / www.nytimes.com/cwire/2010/11/22/22climatewirerepublicans-learn-the-perils-of-being-politic-3326.html(accessed on 14 November 2017).

Lienesch, Michael. 1993. Redeeming America: Piety and Politics in the New Christian Right. Chapel Hill: University of North Carolina Press.

Lindsay, Michael D. 2007. Faith in the Halls of Power: How Evangelicals Joined the American Elite. New York: Oxford University Press.

Lipton, Eric. 2014. Energy Firms in Secretive Alliance with Attorneys General. New York Times, December 6. Available online: https:/ / www.nytimes.com/2014/12/07/us/politics/energy-firms-in-secretive-alliancewith-attorneys-general.html?_r=0(accessed on 27 February 2015).

Lowie, Robert. 1970. Primitive Religion. New York: Liverlight Publishing.

Louisiana Science Education Act (LSEA). 2008. Available online: http://ncse.com/files/08_la_sb733-amend.pdf (accessed on 3 September 2015).

Lynerd, Benjamin T. 2014. Republican Theology: The Civil Religion of American Evangelicals. New York: Oxford University Press.

Maibach, E. W., C. Roser-Renouf, and A. Leiserowitz. 2008. Communication and marketing as climate change-intervention assets: A public health perspective. American Journal of Preventive Medicine 35: 488-500. [CrossRef] [PubMed]

McCammack, Brian. 2007. Hot Damned America: Evangelicalism and the Climate Change Policy Debate. American Quarterly 59: 3. [CrossRef]

McCright, Aaron M. 2011. The Politicization of Climate Change and Polarization in the American Public's Views of Global Warming, 2001-2010. The Sociological Quarterly 52: 155-94. [CrossRef]

Nagle, John C. 2008. The Evangelical Debate over Climate Change. University of St. Thomas Law Journal 5: 52-86.

Nazworth, Napp. 2012. Evangelicals and Climate Change: Global Warming Activists. Pt. 2. The Christian Post, June 7. Available online: http:/ / www.christianpost.com/news/evangelicals-and-climate-change-globalwarming-activists-pt-2-75939/(accessed on 29 May 2015).

NIPCC. 2017. Nongovernmental International Panel on Climate Change website. Available online: http:// climatechangereconsidered.org (accessed on 15 November 2017).

Palmer, Lisa. 2012. Emerging Force on Climate Change: Religion, Ecology, Ethics, and Morality. The Yale Forum on Climate Change \& The Media. November 30. Available online: http:/ / www.yaleclimateconnections. org/2012/11/emerging-force-on-climate-change-religion-ecology-ethics-and-morality/ (accessed on 2 November 2015). 
Pew Research Center's Forum on Religion \& Public Life. 2004. Religion and the Environment: Polls Show Strong Backing for Environmental Protection across Religious Groups. Available online: http:/ / www.pewforum.org/2004/11/02/religion-and-the-environment-polls-show-strong-backing-forenvironmental-protection-across-religious-groups/ (accessed on 19 September 2015).

Pew Research Center's Forum on Religion \& Public Life. 2006. Many Americans Uneasy with Mix of Religion and Politics. Available online: http:/ /www.pewforum.org/2009/04/16/religious-groups-views-on-globalwarming/ (accessed on 19 September 2015).

Pew Research Center's Forum on Religion \& Public Life. 2009. Religious Groups' Views on Global Warming. Available online: http:/ / www.pewforum.org/2009/04/16/religious-groups-views-on-global-warming/ (accessed on 20 September 2015).

Pew Research Center's Forum on Religion \& Public Life. 2011. The Tea Party and Religion. Available online: http:/ / www.pewforum.org/2011/02/23/tea-party-and-religion/\#ftn2 (accessed on 25 October 2015).

Posas, Paul J. 2007. Roles of Religion and Ethics in Addressing Climate Change. Ethics in Science and Environmental Politics 6: 31-49. [CrossRef]

PRRI/AAR. 2014. National Survey on Religion, Values, and Climate Change. Paper presented at AAR Plenary Sessions at the 2014 Annual Meetings, San Diego, CA, USA, 22-25 November.

PRRI/RNS. 2011. Religion News Survey, September 2011. (American) Public Religion Research Institute PRRI. Available online: http:/ / www.thearda.com/Archive/Files/Descriptions/PRRIRNSP.asp (accessed on 5 December 2015).

Radin, Paul. 1957. Primitive Religion. New York: Dover.

Reder, Michael. 2012. Religion in the Public Sphere: The Social Function of Religion in the Context of Climate Change and Development Policy. In Religion in Environmental and Climate Change: Suffering, Values and Lifestyles. Edited by D. Gerten and S. Bergmann. London: Continuum, pp. 32-45.

Revkin, Andrew C. 2009. Skeptics Dispute Climate Worries and Each Other. New York Times. Available online: http:/ / www.nytimes.com/2009/03/09/science/earth/09climate.html?pagewanted=all(accessed on 9 November 2017).

Reynolds, Vernon, and Ralph Tanner. 1995. The Social Ecology of Religion. New York: Oxford University Press.

Rolston, Holmes. 2004. This Sacred Earth: Religion, Nature, Environment. Edited by Rodger S. Gottlieb. New York: Routledge.

Schultz, P. Wesley, Lynnette Zelezny, and Nancy J. Dalrymple. 2000. A multinational perspective on the relation between Judeo-Christian religious beliefs and attitudes of environmental concern. Environment and Behavior 32: 576-91. [CrossRef]

Shaiko, Ronald G. 1987. Religion, Politics, and Environmental Concern: A powerful Mix of Passions. Social Science Quarterly 68: 244-62.

Sherkat, Darren E., and Christopher G. Ellison. 2007. Structuring the religion-environment connection: identifying religious influences on environmental concern and activism. Journal for the Scientific Study of Religion 46: 71-85. [CrossRef]

Shibley, Mark A., and Jonathon L. Wiggins. 1997. The Greening of Mainline American Religion: A Sociological Analysis of the Environmental Ethics of the National Religious Partnership for the Environment. Social Compass 44: 333-48. [CrossRef]

Simmons, J. Aaron. 2009. Evangelical Environmentalism: Oxymoron or Opportunity? Worldviews 13: 40-71. [CrossRef]

Smith, Nicholas, and Anthony Leiserowitz. 2013. American Evangelicals and Global Warming. Global Environmental Change 23: 1009-17. [CrossRef]

Spencer, Roy W., Paul K. Driessen, and E. Calvin Beisner. 2005. An Examination of the Scientific, Ethical and Theological Implications of Climate Change Policy. Burke: Interfaith Stewardship Alliance, Available online: http:/ / www.cornwallalliance.org/docs/an-examination-of-the-scientific-ethical-and-theologicalimplications-of-climate-change-policy.pdf (accessed on 10 October 2015).

Taylor, Bron. 2005. Religious Studies and Environmental Concern. In Encyclopedia of Religion and Nature. London \& New York: Continuum.

Tucker, Mary Evelyn, and John A. Grim. 2001. Introduction: The Emerging Alliance of World Religions and Ecology. Daedalus 130: 1-22. 
Veldman, Robin Globus. 2012. Narrating the environmental apocalypse: How imagining the end facilitates moral reasoning among environmental activists. Ethics \& the Environment 17: 1-23.

Veldman, Robin Globus, Andrew Szasz, and Randolph Haluza-DeLay. 2012. Introduction: Climate Change and Religion-A Review of Existing Research. Journal for the Study of Religion Nature and Culture 6: 255-75. [CrossRef]

Veldman, Robin Globus, Andrew Szasz, and Randolph Haluza-DeLay, eds. 2014. How the World's Religions are Responding to Climate Change: Social Scientific Investigations. New York: Routeledge.

Wanliss, James. 2010. Resisting the Green Dragon: Dominion, Not Death. Burke: The Cornwall Alliance for the Stewardship of Creation.

White, Lynn. 1967. The Historical Roots of our Ecological Crisis. Science 155: 1203-7. [CrossRef] [PubMed]

Wilkinson, Katharine K. 2012. Between God and Green: How Evangelicals Are Cultivating a Middle Ground on Climate Change. New York: Oxford University Press.

C 2017 by the author. Licensee MDPI, Basel, Switzerland. This article is an open access article distributed under the terms and conditions of the Creative Commons Attribution (CC BY) license (http:/ / creativecommons.org/licenses/by/4.0/). 